\title{
Physico-Chemical Characterization of Lodging Tolerance in Rice (Oryza sativa)
}

\author{
N. Anand Rao ${ }^{1 *}$, B. Sreekanth ${ }^{1}$, M. Sheshu Madhav² and S. Narendar Reddy ${ }^{1}$ \\ ${ }^{1}$ Department of crop physiology, Professor Jayashankar Telangana State Agricultural University \\ (PJTSAU), Rajendranagar, Hyderabad, Telangana, India \\ ${ }^{2}$ Department of Biotechnology, Indian Institute of Rice research (IIRR), Rajendranagar, \\ Hyderabad, Telangana, India \\ *Corresponding author
}

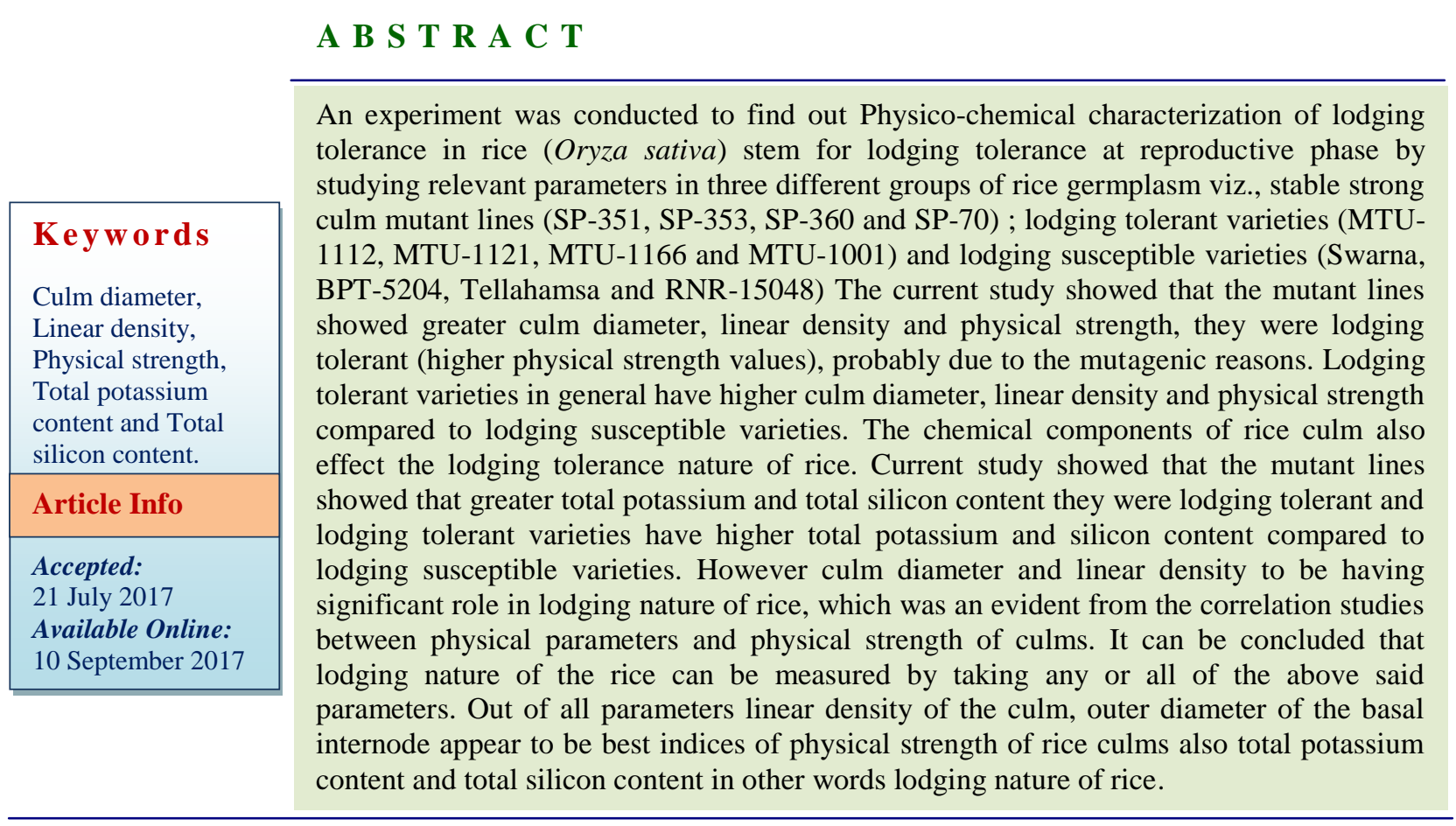

\section{Introduction}

Rice (Oryza sativa L.) is one of the most important staple food crops of Asia, Africa, and South America, and serves as a primary source of food for more than half of the world population (Khush, 2005). It is the main source of the $35-60 \%$ dietary calories consumed by more than 3 billion people (Fageria et al., 2003). It is considered as the world's most diverse crop and is probably the most versatile crop. It is grown below sea level in Kerala, India, at more than $3000 \mathrm{~m}$ elevation in the Himalayas, and at sea level in the deltas of the Asian rivers. It can be found from $53^{\circ}$ North in Northeastern China to $35^{\circ}$ South in New South Wales, Australia. (Mae, 1997; Santos et al., 2003).Total world rice 
production was about 740.9 million tonnes with an area of 160.6 million hectares and in India rice production was about 106.65 million tonnes from 44 million hectares with a productivity of $2462 \mathrm{~kg} / \mathrm{ha}$ (FAO STAT, 2015). Due to the exponential rate of population growth, it is estimated that a $40 \%$ increase in rice yield is needed by 2030 to fulfill the growing demand without affecting the resource base (Khush, 2005). Lodging is usually referred to as that condition in which the stems of crops bend at or near the surface of the ground, which could lead to the collapse of the canopy. It is serious concern which hinders nutrient uptake, raises cost of crop harvesting resulting in lesser farm income increases (Stapper and Fischer, 1990). Lodging in rice may occur as a result of strong winds, heavy rain, improper water management, higher planting density, or an excessive use of fertilizer and the relative impact of a factor will depend on cultivar being grown (Back et al., 1998).

\section{Materials and Methods}

The present experiment was carried out at experimental field of ICAR-Indian Institute of Rice Research, Rajendranagar, Hyderabad and the laboratory of the Department of Crop Physiology, College of Agriculture, Rajendranagar, Hyderabad during kharif, 2014-2015. 12 varieties or lines of rice were taken for the present study to understand the basis of lodging tendency of rice in three different groups of rice germplasm viz., lodging susceptible varieties (Swarna, BPT5204, Tellahamsa and RNR-15048); stable strong culm mutant lines (SP-351, SP-353, SP-360 and SP-70) ; lodging tolerant varieties (MTU-1112, MTU-1121, MTU-1166 and MTU-1001) and lodging susceptible varieties (Swarna, BPT-5204, Tellahamsa and RNR15048) In this Physical and chemical parameters such as culm diameter, linear density of culm and Physical strength of the culm, total potassium content and total silicon content were studied. Stem outer diameter was measured at the third internode of the stem after stripping off leaves and leaf sheaths, by using digital vernier caliper and readings were recorded and expressed in $\mathrm{mm}$. The linear density was measured in terms of dry weight per unit length of total stem length. To calculate the linear density, main stems of rice (from the lower node of third internode to the panicle neck node) were dried to constant dry weight in an oven maintained at $70-75{ }^{\circ} \mathrm{C}$. Linear density was calculated by using the following equation.

\section{Linear density $=\frac{\text { dry weight of stem }}{\text { length of the stem }}$,}

which was expressed in $\mathrm{mg} \mathrm{dwt} \mathrm{cm}^{-1}$. Pushing resistances of the whole plant (hill) was taken as the indicator of physical strength the culms, which was measured with a 'prostrate tester' (DIK-7401, Daiki Rika Kogyo Co., Tokyo, Japan) as per the method reported by Kashiwagi and Ishimaru (2004). The means of the collected data for different characters were analyzed from each group of varieties/ lines i.e., susceptible, tolerant and strong culm mutants and the variety/line with highest means were selected which were compared by using two sample t-test between the varieties and paired t-test within the same variety between the two stages viz., 50\% flowering and full ripening. Rice culm samples (third basal internode) collected from all the varieties/lines under study were dried in hot air oven at about $60^{\circ} \mathrm{C}$ till they attained complete dryness. Samples were then powdered with the help of a mechanical grinder, and passed through $2 \mathrm{~mm}$ stainless steel sieve. Total nitrogen was estimated by the micro Kjeldahl method as per AOAC (1995) using KEL-PLUSTM Automatic Nitrogen Estimation System. Potassium content in the sample was estimated by flame photometric method, as given by Jackson (1967). Si content in rice culms was estimated using the method of Saito et al., (2005), where Si of plant samples was extracted with 
dilutehydrofluoric acid and estimated by spectrophotometric molybdenum yellow method.

\section{Results and Discussion}

Mean values of all the physical and chemical parameters measured at $50 \%$ flowering stage are presented in table 1 . The results showed that the rice varieties/lines differed in all the measured physical parameters mean culm diameter and physical strength and also chemical parameters total potassium content and silicon content were highest in strong culm mutant lines (SP-351, SP-353, SP-360 and SP-70), followed by lodging tolerant varieties (MTU-1112, MTU-1121, MTU1166 and MTU-1001) and lowest in lodging susceptible varieties (Swarna, BPT-5204, Tellahamsa and RNR-15048).

At 50\% flowering stage, rice varieties / lines under study also differed in the mean linear density was highest in SP-360 (76.77 mg.cm ${ }^{1}$ ) and lowest in RNR-15048 (30.38 mg.cm $\left.{ }^{-1}\right)$. Mean length and outer diameter of the basal internode ( $3^{\text {rd }}$ internode), also varied among the rice varieties / lines. View, mutant lines showed higher mean stem diameter of $3^{\text {rd }}$ internode, in which a lowest value of 3.80 $\mathrm{mm}$ was shown by BPT-5204 and a highest value of $8.77 \mathrm{~mm}$ was recorded in SP-360. Mean physical strength was in general highest in mutant lines of rice, highest being in SP$360(30.70 \mathrm{~mm})$, followed by lodging tolerant and lodging susceptible varieties.

However, there was an overlap of values of mean physical strength between lodging tolerant and lodging susceptible rice varieties (Table 1). Lowest mean physical strength $(23.10 \mathrm{~mm})$ was recorded in BPT-5204. Mean values of physical parameters of rice varieties/lines under study at full ripening stage are presented in table 2. As at 50\% flowering stage, mean varieties are at the mid- level, with the exception of RNR-15048, which showed the values comparatively equal to mutant lines of rice. Rice varieties / lines under the present study also differed in mean number of nodes and in mean linear density at full ripening phase (Table 1). Linear density values showed the same kind of groupings as at $50 \%$ flowering stage i.e., highest in mutant lines followed by lodging tolerant varieties and lodging susceptible varieties in the order. Highest linear density value was recorded in the mutant line SP-70 (78.26 $\left.\mathrm{mg} \mathrm{cm}^{-1}\right)$, while RNR-15048 showed lowest value (32.95 $\left.\mathrm{mg} . \mathrm{cm}^{-1}\right)$.

At 50\% flowering stage, total nitrogen content was highest $\left(13.35 \mathrm{mg} . \mathrm{g}^{-1}\right)$ in the mutant line SP-70, while the lodging tolerant variety MTU-1121 showed lowest mean total nitrogen content $\left(11.13 \mathrm{mg} \cdot \mathrm{g}^{-1}\right)$ among all the rice varieties / lines. At full ripening stage, SP-70 (4.55 mg.g ${ }^{-1}$ ) and MTU-1166 (3.62 $\left.\mathrm{mg} . \mathrm{g}^{-1}\right)$ recorded highest and lowest total nitrogen contents of the culm, respectively.

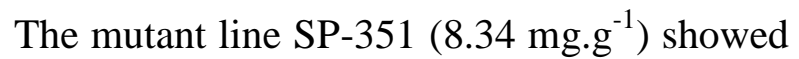
the highest total potassium content at $50 \%$ flowering stage, while Swarna (4.60 mg.g ${ }^{-1}$ ) recorded the lowest. At full ripening stage, a highest total potassium content of $10.59 \mathrm{mg}$. $\mathrm{g}^{-1}$ was seen in SP-70, while a lowest content of $6.09 \mathrm{mg}$. $\mathrm{g}^{-1}$ was observed in the lodging susceptible variety BPT-5204. A highest content of $2.24 \mathrm{mg} \mathrm{g}^{-1}$ and a lowest content of $1.00 \mathrm{mg} \mathrm{g}^{-1}$ of total silicon were found in the mutant line SP-70 and the lodging susceptible BPT-5204, respectively, at 50\% flowering stage among the rice varieties / lines studied.

At full ripening stage, MTU-1166 (2.00 mg. $\left.\mathrm{g}^{-1}\right)$ and RNR-15048 (1.04 mg.g $\left.{ }^{-1}\right)$ showed the highest and lowest contents of silicon in culms, respectively. Total nitrogen, total potassium and total silicon contents of rice culms at 50\% flowering and full ripening stages were compared to know significance of 
change between these two growth stages and the results were presented in table 2 .

This analysis of data showed that the total nitrogen content of rice culms decreased significantly in all varieties between $50 \%$ flowering and full ripening stages (Table 5).

The total potassium content of the rice culms increased significantly in all lodging tolerant varieties and strong culm mutant lines of rice.

In lodging susceptible rice varieties potassium content of culm significantly increased in the variety Swarna (from 4.60 to $6.50 \mathrm{mg}^{-\mathrm{g}^{-1}}$ ), significantly decreased in the variety BPT-

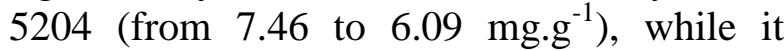

decreased but non-significantly in the varieties Tellahamsa and RNR-15048 (Table 5).

Total silicon content of rice culms didn't change between $50 \%$ flowering and full ripening stages in all the lodging tolerant rice varieties. There was non-significant increase in $\mathrm{Si}$ content in lodging susceptible Swarna and BPT-5204, but significant decrease in Tellahamsa and RNR-15048 with maturity.

In the rice mutant lines, with maturity $\mathrm{Si}$ content of culms decreased significantly in all, except in SP-353 in which there was nonsignificant decrease.

Table.1 Physical-chemical parameters of culm at 50\% flowering stage in rice (Mean of 10 samples)

\begin{tabular}{|l|c|c|c|c|c|}
\hline \multicolumn{1}{|c|}{ Variety / line } & $\begin{array}{c}\text { Culm } \\
\text { diameter } \\
(\mathbf{m m})\end{array}$ & $\begin{array}{c}\text { Linear } \\
\text { density } \\
(\mathbf{m g . c m}\end{array}$ & $\begin{array}{c}\text { Physical } \\
\text { strength } \\
\text { (mm } \\
\text { deflection) }\end{array}$ & $\begin{array}{c}\text { Potassium } \\
\text { (mg.g } \\
\text { dwt) }\end{array}$ & $\begin{array}{c}\text { Silicon } \\
\text { (mg.g } \\
\text { dwt) }\end{array}$ \\
\hline SWARNA & 4.00 & 46.65 & 23.90 & 4.60 & 1.04 \\
\hline BPT5204 & 3.80 & 37.50 & 23.10 & 7.46 & 1.00 \\
\hline TELLAHAMSA & 4.40 & 47.24 & 24.30 & 7.54 & 1.48 \\
\hline RNR15048 & 5.10 & 30.38 & 24.00 & 7.15 & 1.24 \\
\hline MTU1112 & 4.50 & 44.39 & 24.40 & 6.81 & 1.28 \\
\hline MTU1121 & 4.70 & 46.67 & 23.70 & 7.32 & 1.56 \\
\hline MTU1166 & 4.20 & 57.60 & 25.50 & 6.73 & 2.00 \\
\hline MTU1001 & 4.50 & 60.05 & 25.20 & 7.02 & 1.44 \\
\hline SP-351 & 6.00 & 56.46 & 29.60 & 8.3 & 2.00 \\
\hline SP-353 & 6.60 & 65.80 & 29.90 & 8.04 & 1.84 \\
\hline SP-360 & 8.77 & 76.77 & 30.70 & 8.29 & 2.16 \\
\hline SP-70 & 8.68 & 75.93 & 27.80 & 8.03 & 2.24 \\
\hline
\end{tabular}


Table.2 Physical-chemical parameters of culm at full ripening stage in rice (Mean of 10 samples)

\begin{tabular}{|c|c|c|c|c|c|}
\hline Variety / line & $\begin{array}{c}\text { Culm } \\
\text { diameter } \\
(\mathrm{mm})\end{array}$ & $\begin{array}{c}\text { Linear } \\
\text { density } \\
\left(\mathbf{m g} \cdot \mathrm{cm}^{-1}\right)\end{array}$ & $\begin{array}{l}\text { Physical } \\
\text { strength } \\
\text { (mm } \\
\text { deflection) }\end{array}$ & $\begin{array}{l}\text { Potassium } \\
\text { (mg.g } \\
\text { dwt) }\end{array}$ & $\begin{array}{l}\text { Silicon } \\
\left(\mathrm{mg}^{-1}{ }^{-1}\right. \\
\text { dwt) }\end{array}$ \\
\hline SWARNA & 4.20 & 44.04 & 23.80 & 6.50 & 1.13 \\
\hline BPT5204 & 3.80 & 39.13 & 22.90 & 6.09 & 1.08 \\
\hline TELLAHAMSA & 4.50 & 47.46 & 24.30 & 7.33 & 1.16 \\
\hline RNR15048 & 5.20 & 32.95 & 25.00 & 6.91 & 1.04 \\
\hline MTU1112 & 4.60 & 56.93 & 26.20 & 10.41 & 1.28 \\
\hline MTU1121 & 5.20 & 64.83 & 26.20 & 9.11 & 1.56 \\
\hline MTU1166 & 4.60 & 63.62 & 25.60 & 9.49 & 2.00 \\
\hline MTU1001 & 4.40 & 47.48 & 24.40 & 9.26 & 1.44 \\
\hline SP-351 & 6.60 & 56.46 & 29.00 & 8.99 & 1.60 \\
\hline SP-353 & 7.20 & 56.54 & 28.40 & 9.52 & 1.68 \\
\hline SP-360 & 8.80 & 64.09 & 31.40 & 8.29 & 2.16 \\
\hline SP-70 & 8.60 & 78.26 & 31.60 & 8.03 & 2.24 \\
\hline
\end{tabular}

Table.3 Changes in the physical parameters of culm with maturity in rice

\begin{tabular}{|l|c|l|c|c|c|}
\hline \multirow{2}{*}{$\begin{array}{l}\text { Sl. } \\
\text { No. }\end{array}$} & Variety / line & \multirow{2}{*}{$\begin{array}{c}\text { Physical- } \\
\text { parameter }\end{array}$} & $\begin{array}{c}\text { At 50\% } \\
\text { flowering } \\
\text { stage }\end{array}$ & $\begin{array}{c}\text { At full } \\
\text { ripening } \\
\text { stage }\end{array}$ & 'tudent's \\
't' value \\
\hline 1. & Swarna & Culm diameter & 4.00 & 4.20 & $2.583^{*}$ \\
\hline & & Linear density & 46.65 & 44.05 & $1.851^{*}$ \\
\hline & & Physical strength & 23.90 & 23.80 & $0.165^{\mathrm{NS}}$ \\
\hline 2. & BPT 5204 & Culm diameter & 3.80 & 3.80 & $0.000^{\mathrm{NS}}$ \\
\hline & & Linear density & 37.50 & 39.13 & $1.006^{\mathrm{NS}}$ \\
\hline & & Physical strength & 23.10 & 22.90 & $0.348^{\mathrm{NS}}$ \\
\hline 3. & TELLAHAMSA & Culm diameter & 4.40 & 4.50 & $1.750^{*}$ \\
\hline & & Linear density & 47.24 & 47.46 & $0.118^{\mathrm{NS}}$ \\
\hline & & Physical strength & 24.30 & 24.30 & $0.000^{\mathrm{NS}}$ \\
\hline 4. & RNR15048 & Culm diameter & 5.10 & 5.20 & $0.547^{\mathrm{NS}}$ \\
\hline & & Linear density & 30.38 & 32.96 & $2.773^{*}$ \\
\hline & & Physical strength & 24.00 & 25.00 & $1.677^{\mathrm{NS}}$ \\
\hline 5. & MTU112 & Culm diameter & 4.50 & 4.60 & $0.418^{\mathrm{NS}}$ \\
\hline & & Linear density & 44.39 & 56.94 & $4.171^{*}$ \\
\hline & & Physical strength & 24.40 & 26.20 & $6.194^{*}$ \\
\hline 6. & MTU1121 & Culm diameter & 4.70 & 5.20 & $0.474^{\mathrm{NS}}$ \\
\hline & & Linear density & 46.67 & 64.84 & $6.378^{*}$ \\
\hline & & Physical strength & 23.70 & 26.20 & $3.478^{*}$ \\
\hline 7. & MTU 1166 & Culm diameter & 4.20 & 4.60 & $2.143^{*}$ \\
\hline & & Linear density & 57.60 & 63.63 & $1.956^{*}$ \\
\hline & & Physical strength & 25.50 & 25.60 & $0.160^{\mathrm{NS}}$ \\
\hline
\end{tabular}


Table.4 Changes in the physical parameters of culm with maturity in rice

\begin{tabular}{|l|l|l|c|c|c|}
\hline \multirow{2}{*}{$\begin{array}{c}\text { Sl. } \\
\text { No. }\end{array}$} & Variety / line & $\begin{array}{c}\text { Physical-chemical } \\
\text { parameter }\end{array}$ & \multicolumn{2}{|c|}{ Mean } & Student's 't' \\
value \\
\cline { 4 - 5 } & & & $\begin{array}{c}\text { At 50\% flowering } \\
\text { stage }\end{array}$ & $\begin{array}{c}\text { At full ripening } \\
\text { stage }\end{array}$ & \\
\hline 8. & MTU 1001 & Culm diameter & 4.50 & 4.40 & $4.630^{*}$ \\
\hline & & Linear density & 60.05 & 47.48 & $2.881^{*}$ \\
\hline & & Physical strength & 25.20 & 24.40 & $1.444^{\text {NS }}$ \\
\hline 9. & SP 351 & Culm diameter & 6.00 & 6.60 & $6.041^{*}$ \\
\hline & & Linear density & 56.46 & 56.46 & $0.000^{\text {NS }}$ \\
\hline & & Physical strength & 23.10 & 22.90 & $0.348^{\text {NS }}$ \\
\hline 10. & SP 353 & Culm diameter & 6.60 & 7.20 & $4.033^{*}$ \\
\hline & & Linear density & 65.80 & 56.54 & $3.135^{*}$ \\
\hline & & Physical strength & 29.90 & 28.40 & $1.963^{*}$ \\
\hline 11. & SP 360 & Culm diameter & 8.77 & 8.80 & $2.514^{*}$ \\
\hline & & Linear density & 76.77 & 64.09 & $3.202^{*}$ \\
\hline & & Physical strength & 30.70 & 31.40 & $0.782^{\text {NS }}$ \\
\hline 12 & SP 70 & Culm diameter & 8.68 & 8.60 & $4.253^{*}$ \\
\hline & & Linear density & 75.93 & 78.27 & $1.126^{\text {NS }}$ \\
\hline & & Physical strength & 27.80 & 31.60 & $3.739^{*}$ \\
\hline
\end{tabular}

$*$ Significant at 5\% level, NS Non-significant

Table.5 Changes in the chemical parameters of culm with maturity in rice

\begin{tabular}{|c|c|c|c|c|c|}
\hline \multirow{2}{*}{$\begin{array}{l}\text { Sl. } \\
\text { No. }\end{array}$} & \multirow[t]{2}{*}{ Variety / line } & \multirow{2}{*}{$\begin{array}{c}\text { Physical-chemical } \\
\text { parameter }\end{array}$} & \multicolumn{2}{|c|}{ Mean Content (mg.g $\left.{ }^{-1} \mathrm{dwt}\right)$} & \multirow{2}{*}{$\begin{array}{l}\text { Student's ' } t \text { ' } \\
\text { value }\end{array}$} \\
\hline & & & $\begin{array}{c}\text { At 50\% } \\
\text { flowering stage }\end{array}$ & $\begin{array}{c}\text { At full ripening } \\
\text { stage }\end{array}$ & \\
\hline \multirow[t]{2}{*}{1.} & SWARNA & Total potassium content & 4.60 & 6.50 & $7.361^{*}$ \\
\hline & & Total silicon content & 1.04 & 1.13 & $0.673^{\mathrm{NS}}$ \\
\hline \multirow[t]{2}{*}{2.} & BPT5204 & Total potassium content & 7.46 & 6.09 & $5.655^{*}$ \\
\hline & & Total silicon content & 1.00 & 1.08 & $1.000^{\mathrm{NS}}$ \\
\hline \multirow[t]{2}{*}{3.} & TELLAHAMSA & Total potassium content & 7.54 & 7.33 & $0.679^{\mathrm{NS}}$ \\
\hline & & Total silicon content & 1.48 & 1.16 & $1.809^{*}$ \\
\hline \multirow[t]{2}{*}{4.} & RNR15048 & Total potassium content & 7.15 & 6.91 & $1.359^{\mathrm{NS}}$ \\
\hline & & Total silicon content & 1.24 & 1.04 & $2.236^{*}$ \\
\hline \multirow[t]{2}{*}{5.} & MTU1112 & Total potassium content & 6.81 & 10.41 & $12.170^{*}$ \\
\hline & & Total silicon content & 1.28 & 1.28 & $0.000^{\mathrm{NS}}$ \\
\hline \multirow[t]{2}{*}{6.} & MTU1121 & Total potassium content & 7.32 & 9.11 & $5.352^{*}$ \\
\hline & & Total silicon content & 1.56 & 1.56 & $0.000^{\mathrm{NS}}$ \\
\hline \multirow[t]{2}{*}{7.} & MTU1166 & Total potassium content & 6.73 & 9.49 & $8.418^{*}$ \\
\hline & & Total silicon content & 2.00 & 2.00 & $0.000^{\mathrm{NS}}$ \\
\hline \multirow[t]{2}{*}{8.} & MTU1001 & Total potassium content & 7.02 & 9.26 & $9.798^{*}$ \\
\hline & & Total silicon content & 1.44 & 1.44 & $0.000^{\mathrm{NS}}$ \\
\hline \multirow[t]{2}{*}{9.} & SP 351 & Total potassium content & 8.34 & 8.99 & $2.153^{*}$ \\
\hline & & Total silicon content & 2.00 & 1.60 & $4.743^{*}$ \\
\hline \multirow[t]{2}{*}{10.} & SP353 & Total potassium content & 8.04 & 9.52 & $6.843^{*}$ \\
\hline & & Total silicon content & 1.84 & 1.68 & $0.712^{\mathrm{NS}}$ \\
\hline \multirow[t]{2}{*}{11.} & SP 360 & Total potassium content & 8.29 & 10.17 & $7.472^{*}$ \\
\hline & & Total silicon content & 2.16 & 1.60 & $5.252^{*}$ \\
\hline \multirow[t]{2}{*}{12} & SP 70 & Total potassium content & 8.03 & 10.59 & $7.870^{*}$ \\
\hline & & Total silicon content & 2.24 & 1.76 & $4.810^{*}$ \\
\hline
\end{tabular}

$*$ Significant at $5 \%$ level, NS Non-significant 
Table.6 Correlation between physical -chemical parameter of the culm and Physical strength of the culm in rice

\begin{tabular}{|c|l|c|c|}
\hline Sl. & Physical-chemical & \multicolumn{2}{|c|}{ Correlation coefficient (r) with physical strength } \\
\cline { 3 - 4 } No. & Parameter & 50\% flowering stage & Full ripening stage \\
\hline 1. & Culm diameter & $0.960^{* * *}$ & $0.906^{* *}$ \\
\hline 2. & Linear density & $0.826^{* *}$ & $0.570^{*}$ \\
\hline 3. & Total potassium content & $0.626^{* *}$ & $0.749^{* *}$ \\
\hline 4. & Total silicon content & $0.813^{* *}$ & $0.628^{*}$ \\
\hline
\end{tabular}

Mutant lines of rice showed relatively higher values of mean stem diameter at full ripening phase (Table 1). RNR-15048 differed from other lodging susceptible varieties by showing higher value of mean stem diameter comparable to lodging tolerant varieties.

Intra-varietal changes in physical parameters of rice with maturity between $50 \%$ flowering and full ripening, were tested for significance and the results are presented in tables 3, 4 and 5. Mean outer diameter of rice culm at $3^{\text {rd }}$ internode significantly increased in all strong culm mutant lines as well as in the lodging susceptible variety Swarna. But in other varieties the changes are non-significant (Table 3).

Mean linear density of the culm increased significantly between $50 \%$ flowering and full ripening in RNR-15048, MTU-1112, MTU1121 and MTU-1166, while it decreased significantly in Swarna, MTU-1001, SP-353 and SP-70 (Table 1). Physical strength of the rice culms which was measured as the pushing resistance of the rice hills, significantly increased between $50 \%$ flowering and full ripening stages in MTU1112, MTU-1121 and SP-70 and significantly decreased only in the mutant line SP-353. In all others changes in physical strength were significant (Table 3). Lower contents of nitrogen and higher contents of potassium in rice internodes decreased lodging tendency (Mahbub et al., 2008). The results from the current study show clearly those strong culm mutant lines had higher potassium contents followed by lodging tolerant varieties in the culms, both at $50 \%$ flowering and full ripening stages

Correlation between the physical and chemical parameters of rice and its physical strength, varietal means of physical parameters of rice were correlated to varietal means of physical strength (Table 6), at both $50 \%$ flowering and full ripening stages. At $50 \%$ flowering stage, even though all the measured physical and chemical parameters viz., outer diameter of basal $\left(3^{\text {rd }}\right)$ internode, linear density of culm, potassium and silicon content showed positive correlation with physical strength of culm. Further, culm diameter and linear density showed significantly positive correlation even at $1 \%$ level of significance (Table 6). Correlation between physical-chemical parameters and physical strength of rice culms at full ripening stage was similar to that of $50 \%$ flowering stage i.e., all parameters showed positive correlation with physical strength; culm diameter, linear density, total potassium content and silicon content showed significant correlation.

The present study accepts the general statement that compared to tolerant varieties; susceptible varieties had lesser culm diameter, which are in line with the findings of (Chang and Vergara, 1972, Rongtian et al., 1996 and Mahbub et al., 2008). Here also the mutant lines are different by having higher diameter. 
Linear density of the culm was highest in mutant lines followed by lodging tolerant varieties and then by lodging susceptible varieties. These findings agree with the reports of Zuber et al., (1999) and Islam et al., (2007), which say that higher the linear density higher the lodging resistance. Out of all parameters linear density of the culm, outer diameter of the basal internode appear to be best indices of physical strength of rice culms in other words lodging nature of rice. Various physical-chemical parameters viz., outer diameter of basal $\left(3^{\text {rd }}\right)$ internode, linear density of culm, total potassium content and total silicon content were studied along with physical strength of the culms, to understand the physical-chemical basis of lodging nature in rice. Physical-chemical data was collected at $50 \%$ flowering stage as well as full ripening stage to know the changes in them with maturity in rice. The current study showed that lodging tolerant varieties in general have higher outer diameter of basal internode $\left(3^{\text {rd }}\right.$ internode $)$, higher linear density and higher physical strength of culms compared to lodging susceptible varieties. It can be concluded that lodging nature of the rice can be measured by taking any or all of these parameters linear density of the culm, outer diameter of the basal inter node, total potassium content and total silicon content appear to be best indices of physical strength of rice culms in other words lodging nature of rice. However, nitrogen contents of the culm didn't differ much between lodging susceptible and tolerant varieties; moreover they were higher in strong culm lines. The present study also reports a significant correlation between physical strength of the culm and culm $\mathrm{N}$ and $\mathrm{K}$ contents at both $50 \%$ flowering and full ripening stages, which are in agreement with the findings of Yang et al., (2004) and Zhang et al., (2010). However, it should pointed out that the current study shows that Nitrogen content of culms played a significant role in physical strength of culms at $50 \%$ flowering, but not at full ripening stage (Table 1).

\section{References}

Back, N.H., Kim, S.S., Choi, M.G., Yang, W.H., Shin, H.T and Cho, S.Y. 1998. Effect of slow release compound fertilizer application rate on growth and yield of rice in direct seeding on flooded paddy surface. RDA Journal of Agro-Environmental Science. 40: 35-41

Bhiah, K. M., Guppy, C., Lockwood, P. and Jessop, R. 2010. Effect of potassium on rice lodging under high nitrogen nutrition. Paper presented in 19th World Congress of Soil Science, Soil Solutions for a Changing World, $1-6$ August 2010, Brisbane, Australia. 136-139.

Fageria, N.K., Slaton, N.A and Baligar, V.C. 2003. Nutrient management for improving lowland rice productivity and sustainability. Advances in Agronomy. 80:63-152.

Islam, M.S., Peng, S., Visperas, R.M., Ereful, N., Bhuiya, M.S and Julfiquar, A.W. 2007. Lodging related morphological traits of hybrid rice in a tropical irrigated ecosystem. Field Crops Research. 101: 240-248.

Kashiwagi, T., and Ishimaru, K. 2004. Identification and functional analysis of a locus for improvement of lodging resistance in rice. Plant Physiology. Japan. 134: 676-683.

Khush, G.S., 2005. What it will take to feed 5.0 billion rice consumers in 2030 . Plant Molecular Biology. 59:1-6.

Lee, T.S., Kwon, T.O. and. Park, K.H. 1990. Influence of nitrogen and silicon on the yield and the lodging related traits of rice. Soil Fertility. 32: 15-23.

Liang, Y.C., Ma, T.S., Li, F.J. and Feng, Y.J. 1994. Silicon availability and response of rice and wheat to silicon in calcareous soils. Communications in 
Soil Science and Plant Analysis. 25: 2285-2297.

Mae, T., 1997. Physiological nitrogen efficiency in rice. Nitrogen utilization, photosynthesis, and yield potential. Plant and Soil. 196:201-210.

Mahbub, M.A.A., Khanam, M., Rahman, M.S., Hossain, M.A and Gomosta, A. R. 2008. Determination of lodging characters of some BRRI recommended rice varieties at three nitrogen levels during wet season in Bangladesh. Bangladesh Journal of Botany. 35:117124.

Stapper, M., and Fischer, R. A. 1990. Genotype, sowing date and plant spacing influence on high yielding irrigated wheat in southern New South Wales. III Potential yields and optimum flowering dates. Australian Journal of
Agricultural Research.41: 1043-1056. Yang, C.M., Yang, L. Z., Yan, T.M and Ou, Y.Z. 2004. Effects of nutrient and water regimes on lodging resistance of rice. Journal of Applied Ecology. 15(4): 646650. (In Chinese with English abstract).

Zhang, F.Z., Jin, Z., Guo-hui, M.A., Shang, W., Liu H., Mei-lan, X and Liu, Y. 2010. Relationship between lodging resistance and chemical contents in culms and sheaths of Japonica rice during grain filling. Rice Science. 17: 311-318.

Zuber, U., Winzeler, H., Messmer, M.M., Keller, B., Schmid, J.E and Stamp P. 1999. Morphological traits associated with lodging resistance of spring wheat (Triticum aestivum L.). Journal of Agronomy and Crop Science. 182: 1724.

\section{How to cite this article:}

Anand Rao, N., B. Sreekanth, M. Sheshu Madhav and Narendar Reddy, S. 2017. PhysicoChemical Characterization of Lodging Tolerance in Rice (Oryza sativa). Int.J.Curr.Microbiol.App.Sci. 6(9): 1770-1778. doi: https://doi.org/10.20546/ijcmas.2017.609.219 